\title{
The Utilization of Local Wisdom to Develop an Environment-Based Vocational School a Preliminary Study
}

\author{
Urip Wahyuningsih \\ Department of Home Economics \\ Universitas Negeri Surabaya \\ Surabaya, Indonesia \\ uripwahyu@gmail.com
}

\author{
Rodia Syamwil, Sri Endah Wahyuningsih, \\ Muhammad Fahrihun Na'am \\ Department of Home Economics \\ Universitas Negeri Semarang \\ Semarang, Indonesia
}

\begin{abstract}
The utilization of local wisdom to develop an environment-based vocational school model was a preliminary study. This model analyzed the relationship between school policy aspects, learning approaches, location, and potential local wisdom to obtain an environment-based curriculum. Data collection used was: observation, documentation, interviews with school management, and educational stakeholdersm and literature review. The results were mapping of all community's environmental potentials, the environment-based education and learning model that takes into consideration all aspects of potential, especially on local wisdom.
\end{abstract}

\section{Keywords -Nature Integrated School}

\section{INTRODUCTION}

Government policies in education development center on improving quality, access, and relevance. Various efforts made by the government to improve the quality of education, because it will be obtained the next qualified nation generation as well. It is increasingly realized that Indonesia needs intelligent and cautious human resources. Intelligence must be balanced with devotion, so that intelligence will not become harmful and cause damage. Character building is a very important issue right now, and this is reflected in the 2013 Curriculum that is being applied. Integrated Islamic School is a school that prioritizes character education based on Islamic principles, by integrating public education with religion in its curriculum.

The presence of Nature Integrated School (SAT) provides a new color for education in Indonesia, especially in Central Java. The purpose of this school establishment is to bring students or learners closer to nature, among others, by learning in the open, learning directly from learning resources contained in the school environment.

One example of the Nature Integrated School (SAT) is in the area of Limbangan Kendal Central Java. Natural atmosphere in Limbangan should be very supportive also create a fun learning atmosphere. However, in reality this school has not optimally utilized the natural atmosphere and its natural potential, as well as other environmental potentials such as community culture, economic potential, and so on.

The Nature Integrated School (SAT) at Limbangan Kendal holds continuous education programs from elementary school, junior high school, to Vocational High School. The utilization of the environment as a source of learning is mostly done at the level of primary education, namely elementary and junior high school. However, at the Vocational High level, the utilization of this environment is no longer a priority in this school. This may be due to a lack of exploration of environmental resources that can be utilized as a learning resource. In addition, teachers in school are not aware of the enormous potency that region has to develop as an advantage and uniqueness. Therefore, this schools need to be helped to use the environmental potency, so that the concept of Integrated Nature School can be realized perfectly.

Vocational High School is a vocational education level that prepares its graduates to enter the employment field. Vocational high School Programming skills of Dress Fashion, Culinary, Beauty is the path of education closest to the livelihood of many people. This educational pathway provides the knowledge and skills and attitudes associated with the production of clothing, culinary, and beauty services, which are indispensable in society. However, in the educational process, these three skills programs require relatively high costs, especially if the raw materials are bought in stores or markets. Utilization of the environment will provide savings efforts.

The research, "The utilization of local wisdom to develop a model of environment-based vocational schools" intended to develop an educational model that includes an environmentbased curriculum, the development of infrastructure facilities from the natural environment, potential local-based learning designs owned by the region, in an integrated manner. This model will help schools in realizing the concept of education 
in accordance with the concept of nature and explore the local potential that exists, so that create a less expensive education, efficient, and beneficial for the environment.

\section{METHODS}

\section{A. Previous Research}

Earlier studies in particular that have made the object of research of a natural school (an environment-based school) have not been found. During this time there were dominant conventional schools, Related to learning methods, classroom studies, class actions and so forth. Muhibbin Syahdi in his book entitled, Learning Psychology states factors that influence learning include learning approaches (approach to learning), namely the type of student learning efforts that include strategies and methods used by students to learning lesson material. (Muhibbin Syah, 2007: 144). Thus the research effort on natural schools is very relevant to serve as a model of sustainable alternative learning. The school of nature has indeed become the community's choice as a result of the discovery of the new, progressive and less cost learning methods.

The education basically contributed to students and teachers as well as the wider community started by the readiness of learners to enter the workforce. Therefore the world of education should be able to answer the needed in the world of work. This is relevant to the research result of Sri Handayani (2015) revealed disclosing the role of the community and its relevance, which indicate a high contribution of family and community environmental factors, its implies that in the development Building Engineering Education study program should pay attention to these factor.

Environmental factors play a very active role, including the natural environment around so nature that rich in science resources and benefits are very conducive to the environment and atmosphere in the learning process. Nature teaches many things about the philosophy of life and the process of food chains and ecosystems.

Ernst, (2004), examined the relationship between environment-based education and high school students' critical thinking skills and disposition toward critical thinking. The results of this study support the use of environment-based education for improving critical thinking and can be used to guide future implementation.

American Institutes for Research, (2005), suggested that outdoor education programs may contribute to academic learning and social development for at-risk students in ways that cannot be duplicated within the classroom environment.

On the other hand, Wood C, et all (2014) A Repeated Measures Experiment of School Playing Environment to Increase Physical Activity and Enhance Self-Esteem in UK School Children. The promising trend for the effect of the natural environment on MVPA (Moderate to vigorous Physical Activities) indicated that interventions aimed at increasing MVPA should use the natural environment and that schools should encourage greater use of their natural areas to increase Physical Activities.
Some of the above researches showed how important the surrounding environment in improving the quality of student learning. Dillon et al. (2008), found substantial evidence to indicate that fieldwork, properly conceived, adequately planned, well taught and effectively followed up, offers learners opportunities to develop their knowledge and skills in ways that add value to their everyday experiences in the class rooms.

Around the world teachers were very important professionals group; in some developing countries they were the largest income earner. All this must be supplemented by a general trend toward the expansion of the non-school education sector. The illiteracy effort for adults began to advance, and the distinction between formal primary education and reading and writing programs began to blur (Edgar Faure, 1980; 21).

Role of Professionalism and Managerial According Mulyasa, E in his book entitled School Based Management. The Principal should be able to take advantage of opportunities and conceptualize new directions of change, in this context the nature integrated school was relatively new and dynamic method of acceptance within society. The importance of a change can be seen from the public interest to respond the change. The systems and methods in natural school learning were created to discover new and effective ways with less building use and more interacting with nature as a reference in subjects.

In general, people doing business or work in order to obtain a lot of results with minimal cost, energy, and time, or in other words efficiency. Efficiency was a concept that reflects the best comparison between effort and outcome (Gie, 1985).[7] The effort was also contained in natural school education, with the orientation school efficiency using an effective method, with nature as an important correlation, but nevertheless the given material still refers to the existing provision, in other words an efficient effort without abandoning the rule of education and principles of the learning process.

\section{B. Research Methods}

This research form was a research and development, to develop an Environmental Based Education Model. This model combines 4 concepts of education, namely: (1) The concept of Vocational Education in accordance with the existing Expertise Program; (2) the concept of character education based on Islam; (3) the concept of utilizing the natural environment; And (4) the concept of community potential utilization.

\section{RESULTS AND DISCUSSION}

The observation of the Nature Integrated School (SAT) in the area of Limbangan Kendal showed that the area of Limbangan was a plateau area with cool natural shades with hilly topography. The road conditions along the Limbangan arch and up and down, however, they can be accessed by various vehicles. Limbangan was an area produced palawija and vegetables, thus some of the surrounding community were 
farmers, but there was a group of batik craftsmen who utilized the plants as natural dyes. The plants that produced dyes cultivated and developed in this area, along with the purpose of environmental conservation.

The location of Integrated Nature School (SAT) in Limbangan has located alongside the Sumowono highway of Brujulan village on the edge of a cliff with ample land. Some of the land has been built semi-permanent buildings with open nature, and some gazebo for learning outside the classroom. Natural-based laboratories just started in the field of agribusiness, through the breeding of orchids and various ornamental plants, while for other new fields at the design stage.

Allen Coop. 2015. Explain a substantial body of research indicated that a $\mathrm{n}$ outdoor learning and play environment with diverse natural elements advances and enriches all of the domains relevant to the development, health, and wellbeing of young children. Despite these findings, the outdoor learning environment goes virtually unmentioned in national and state level standards, guide lines, and regulations, and has been largely overlooked in the considerable efforts to enhance the quality of early childhood education (ECE). Moreover, children most likely to benefit from an outdoor play and learning environment are less likely to have access to one.

The natural world provides rich opportunities for children to develop relationships and to learn about and experience caring for themselves, for others and for plants and animals. In a comparison of school play spaces, researchers found that children play more cooperatively and engage in more creative forms of play in green spaces (Bell \& Dyment, 2006). Children who had regular opportunities for unstructured free play outdoors were healthier, happier and better able to get along with others (Burdette \& Whitaker, 2005).

Learning on the Nature Integrated School (SAT) still referring to an equivalent formal education, with the development of natural-based media, but when viewed from the natural potential it has not been done optimally. This is due to limited human resources. Utilization of waste and environmental conservation was included in the local content curriculum. The founders of nature schools as well as landowners and school donors was Tri Joko Uripno, while the implementation of learning in the school led by Saiful assisted 8 teachers and one administration. All the teachers are scholar graduates in their field, yet still work voluntarily to serve and develop the school become a good nature integrated school (SAT). A good school will easily gain public trust so that the number of students will increase.

Ar Ridho Nature Integrated School also one portrait example of the Nature Integrated School in the area of East Semarang precisely on the road Palm oil 1 Block AA Kencana Jaya Hill was an integrated school of nature from PAUD, kindergarten, elementary, and junior high school. The location of this Integrated School of Nature was in the outskirts of Semarang, a natural atmosphere that still thick, hilly and fresh air. This integrated School of nature located nears the residential area, but the land wide enough so that the development of natural-based laboratory can be fulfilled.

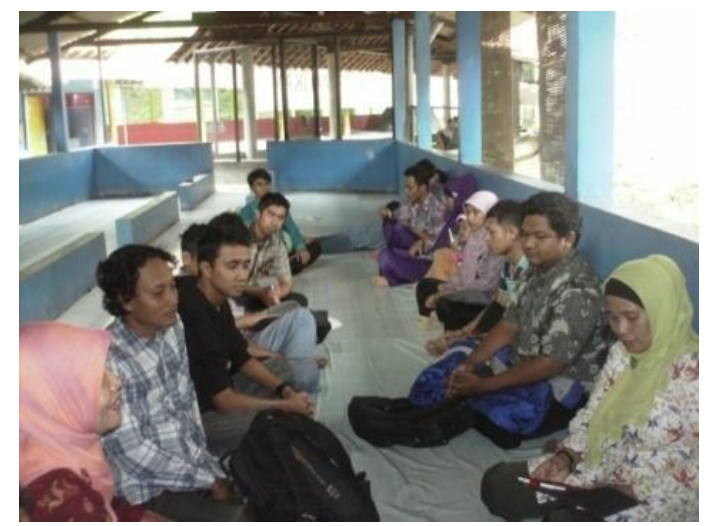

Fig 1. Interview with Headmaster, teacher, manager, and students of Nature Integrates School (SAT) Limbangan Kendal (Source: Nisa, 2013)

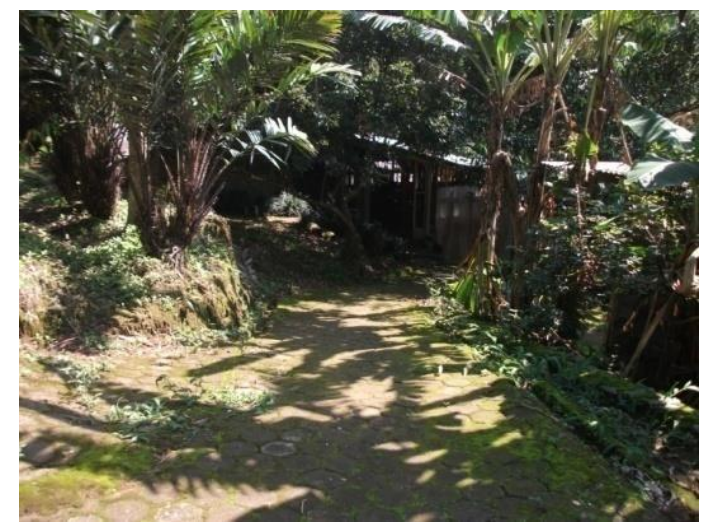

Fig.2. Location of Land in Nature Integrated School (SAT) Limbangan Kendal (Source:Nisa, 2013)

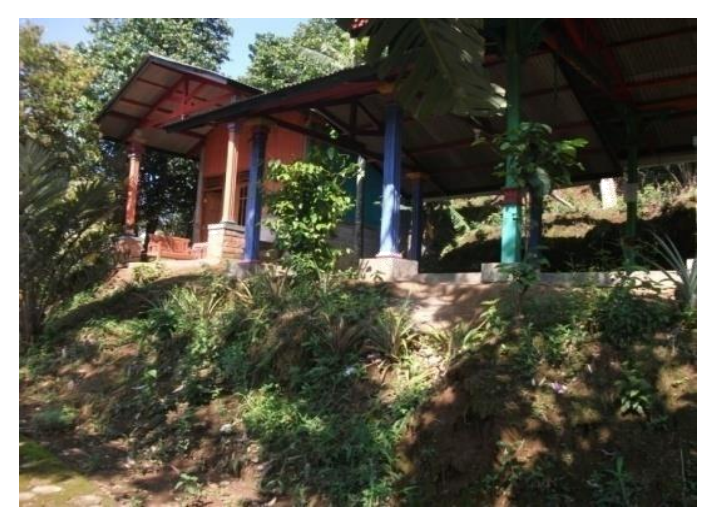

Fig.3. Open Learning Place di Nature Integrated School (SAT) Limbangan Kendal (Source: Nisa, 2013) 
Learning process embraced the curriculum of the Kemendiknas, but not all training courses were followed, the less-educated children's training will be replaced with other knowledge. A unified learning system between formal and religious education that easy for students to understand in accordance with their vision and mission applied. They have a Vision becomes a world class school that always innovate to develop educational methods that make people know how to submit to Allah as Kholifah in every process of learning. While the mission are: educate aqidah, worship and akhaqulkarimah; Educate the character of a scientific and caring leader of the environment; conserve the natural; optimize the whole intelligence; build natural-based intelligence with international standardized learning; Synergize with stakeholders and provide a fun learning environment.

Ideally, the basic concept of the school of nature departs from the values of the Qur'an and sunnah, which stated that the essence of the creation of man become kholifah on earth. Thus, the initiators of the School of nature are convinced that the very essence of the goal of education was to help the students grow into character human beings. Being a man who was not only able to utilize what was available in nature, but also able to love and maintain the environment. Knowledge was not something we should have. Knowledge was a function. As a function, we should learn all the knowledge that helps us change for the better. Learning was the process of using knowledge as a constant approach to perfection. Learning was the process of being constant. Because being a never-ending process, learning was the only never-ending process of life. That is, among others, the foundation of the birth of the School of nature (Maryati, 2007).

The concepts of education applied were: Character Based Learning that integrates the students in the process of character building activities, which include: modeling, awareness, habituation, and motivation. Nature Integrated School (SAT) students trained to be able read the universe with full and whole view of the whole universe divided into themes of the discussion, then students learn to explore the themes through various science in learning activities.

Inquiry Based Learning to build the learning atmosphere with the format that each student is given the title "as scientist" or as a scientist, by arranging the learning with exploration and investigation approach to the object as well as events directly, Multiple Intelligent Based Learning is convinced that each child was unique / different theory then multiple intelligence was placed as a guide teachers in managing children's learning activities.

Green Based Learning was a process of learning with green philosophy include green school environment such as mini forest, water conservation, garbage bank, vegetable garden, plant nursery, healthy canteen, green building (energy efficient, built with ground conservation principle), green media (organic, reduce - reuse - recycle).

Furthermore Maryati, 2007 state in a nature school, students not only learn. Teachers also learn from students, even parents also learn from teachers and children. Children not only study in class, but also they learn anywhere. They were not only learned from books, but from what has been seen around them. They directed to learn actively and independently, the teacher plays more role as facilitator, they do not learn to pursue value, but to be able to use their knowledge in everyday life. The mix of classroom lessons, outbound training, outing, market day and others has provided a relatively more complete awareness and understanding of life, shaped a stable emotional structure and mentality, and built more enlightened daily attitudes from time to time. School was the center of life for students. With a pleasant environment, they enjoyed the center of life without the burden, without stress. School was the reality of life they live with full appreciation. School is a source of excitement, not a source of stress that usually makes them lose their passion.

Learning with harnessing of nature was environmental conservation activity. At present nature has been persecuted by irresponsible parties. The existence of natural school expected keeping life sustainable of the earth in a balanced way.

Cheng, \& Monroe, (2010) explained that exposure to nature provides opportunities to develop a positive and supportive attitude toward nature. Results from a study on children's connection and attitude toward nature found that "connection to nature is a strong predictor of children's interests in environment friendly practices". In other words, children's affiliation with nature may predict their ecological behaviors such as conservation.

Furthermore Berenguer, J. (2010) explained that the development of environmental altruism was related to creating a caring relationship, love and respect for the environment. In this framework then, empathy towards the non -human world means recognizing the needs of animals, and nature in general, the importance of their survival and displaying an interest in their wellbeing.

Aspects of the natural school curriculum were moral, logical cognitive thinking, leadership and utilization of the surrounding natural potential, inculcation value of exemplary all existing components at the location (teachers, parents, community). Moral was to equip the child with the religious values needed to go to maturity. Science integrated the goverment curriculum presented in different methods, making nature as a laboratory in scientific development, nature as a learning medium, study space and as a learning object. Students are expected to have creativity. Leadership: outbound method as a learning media to build character of students based on experience from nature as the main media with the purpose to build a strong character, leadership qualities and cooperation ability was based on noble character. Entrepreneurship: learning through entrepreneurship materials in various fields of science integrated in an activity contract, able to open the spirit of self-employed and competitive entrepreneurs. Natural potential around / local potential: learning by using the natural potential, local culture and utilizing it for creative development.

Gerde, Schachter, \& Wasik, 2013, declared that integrating early childhood education, environmental 
education, and social-emotional supports within and throughout the entirety of an early childhood program helps to enhance holistic child development. A nature -based approach, whether through an entirely outdoor program or through a balance of outside time and bringing nature inside, lends itself to providing rich opportunities for social -emotional development as well as cognitive, physical, and language learning. Nature was dynamic, providing an evolving landscape for children to explore physically, emotionally, and cognitively and lending itself to engage children in scientific processes such as observing, questioning, predicting experimenting, summarizing, and sharing results.

The concept of a natural school was the curriculum not determined to the students just like any other school. This was because students seek and have their own material that they want to know, with unspecified work (choose your own), thus the learning process becomes more focused. Learning process is also in accordance with real life.

Learning by applying spider web method with theme or project based made students sensitive as well as open in listening to the problem and find a solution totaly. Students were able to relate the lesson with real life and at the same time can integrate the lessons with one another. Learning systems, students, teachers and parent alike learn. Students learned not only pursue values but also learned to utilize their knowledge in everyday life. The process teaching and learning was not only in classroom, but with the natural surroundings.

\section{CONCLUSION}

- The development of environment-based educational model adapted to the potential area where the natural school stands. Thus, the curriculum followed local potential and culture.

- UNESA as an university that organizes educational programs with a visionary conservation, it was appropriate to have awareness of education on various levels and regions. UNESA needed to concern conservation values to various levels and pathways of education through environmentally-based programs. Therefore, this research was a form to participation in supporting UNESA program to be disseminated to the public.

\section{REFERENCES}

[1] Muhibbin Syah, 2007. Psikologi Belajar Raja Grafindo Persada, Surabaya.

[2] Ernst, Julie; Monroe, Martha,"The Effects of Environment-Based Education on Students Critical Thinking Skills and Disposition toward Critical Thinking," Environmental Education Research, Taylor \& Francis Group Journals, , Philadelphia, v.10, pp. 507-522 November 2004.

[3] American Institutes for Research, "Effects of Outdoor Education Programs for Children in California" .http://www.air.org/sites/default/files/downloads/report/,2005

[4] Wood C, Gladwell V, Barton J "A Repeated Measures Experiment of School Playing Environment to Increase Physical Activity and Enhance Self-Esteem in UK School Children," PLoSONE9(9):e108701.

http://journals.plos.org/plosone/article?id=10.1371/, 2014.

[5] Dillon et al. "The value of outdoor learning: Evidence from research in the UK and elsewhere," School Science Review, March 2008.

[6] Edgar Faure, 1980. Belajar Untuk Hidup Dunia pendidikan hari kini dan hari esok. Bhratara Karya Aksara, Jakarta

[7] Gie, The Liang. 1985. Cara Belajar yang Efesien. Yogyakarta: Pusat Kemajuan Studi (Centtudy Progress)

[8] Allen Coop."Nature and the Outdoor Learning Environment: The Forgotten Resource in Early Childhood Education," International Journal of Early Childhood Environmental Education, vol. 3, pp. 85-97, 2015.

[9] Bell, A. C., \& Dyment. J. E.,"'Grounds for action: Promoting physical activity through school ground greening in Canada," Toronto, Ontario: Evergreen, 2006.

[10] Burdette, H.L., \& Whitaker, R. C. "Resurrecting free play in young children: Looking beyond fitness and fatness to attention, affiliation, and affect," Archives of Pediatric and Adolescent Medicine, pp. 46-50

[11] Maryati. Sekolah Alam, Alternatif Pendidikan Sains Yang Membebaskan Dan Menyenangkan. Prosiding SeminarNasional Penelitian, Pendidikan dan Penerapan MIPA Yogyakarta, hal. 179-189, 25 Agustus 2007.

[12] Cheng, J. C. H., \& Monroe, M. C, "Connection to nature: Children's affective attitude toward nature" Journal of Environment and Behavior, vol. 44, pp. 31-49, 2010

[13] Berenguer, J, "The effect of empathy in environmental moral reasoning," Journal Environment and Behavior,vol. 42, pp. 110-134, January 2010.

[14] Gerde, H., Schachter, R. E., \& Wasik, B. A. "Using the scientific method to guide learning: An integrated approach to early childhood curriculum," Early Childhood Education Journal, vol. 41, pp. 315-323, 2013

[15] Sri Handayani, Faktor yang dipertimbangkan dalam Upaya Pengembangan Program Studi Teknik Bangunan, Jurusan Teknik Bangunan Fakultas Teknik, Universitas Negeri Semarang, 2015. 